\title{
Rethinking mobility at the urban-transportation-geography nexus
}

\author{
Andrew E.G. Jonas \\ Department of Geography, Environment and Earth Sciences \\ Hull University \\ Hull HU6 7RX \\ United Kingdom \\ A.E.Jonas@hull.ac.uk
}

\begin{abstract}
Author final version October 2014
This is the accepted pre-proof manuscript version of a chapter to appear in J. Cidell and D. Prytherch (eds.) (2015) Transportation, Mobility and the Production of Urban Space (London: Routledge), pp.281-94. Further details at:

http://www.routledgementalhealth.com/books/details/9781138891340/
\end{abstract}

\begin{abstract}
Building on the main sections of the book, this concluding chapter identifies four thematic areas for future research into the urban-transportation-geography nexus as follows: (1) the everyday experience of transport and mobility in the "ordinary city"; (2) the environment and the urban politics of mobility; (3) connected cities and competitive states; and (4) transportation mobility and new imaginaries of city-regional development.
\end{abstract}

\section{Introduction}

The "new mobilities paradigm" (Sheller and Urry 2006) in social and cultural studies is transforming the ways in which scholars think about space - especially urban space (Amin and Thrift 2002). It comes on the back of wider discussions about the spatiality of social life in cities, discussions often inspired by the writings of critical geographers and sociologists, such as Doreen Massey (1991) and Manuel Castells (2000), who place emphasis on understanding how urban processes are constituted through relationships, flows and networks extending far beyond the boundaries of the city. The status of world cities like London, for example, depends upon not just the spatial concentration of global financial institutions 
within city boundaries but also the nature of global connections shaping the social characteristics of its diverse boroughs (Massey 2007). Relational thinking about cities disrupts an overly containerized view of urban space and opens up new vistas for examining cities and their wider social relationships, connections and flows. ${ }^{1}$

This book uses urban transportation as a lens through which to rethink mobility. Whilst there have been previous dialogues between urban scholars and transportation geographers, relational scholars of the urban have been a little slow to recognize quite how profoundly new modalities of transportation shape the conduct and governance of mobility in the city today (Cresswell 2010; Shaw and Hesse 2010; Hall and Hesse 2013). At the same time, and paradoxically, certain tropes familiar to transportation geographers, such as mobility, flow and movement, have increasingly been deployed by critical urban scholars as metaphorical devices for thinking about urban-environmental relations and social injustices in the capitalist city (Heynen, Kaika and Swyngedouw 2006; Kaika 2005). Yet for the most part this has not led to efforts to rethink mobility through the lens of urban transportation per se. By adding transportation to the urban mobility equation, this book significantly deepens and extends the empirical scope of relational thinking about the production of urban space.

In their introduction, the editors identify the epistemological challenge as follows: "how best to comprehend and theorize the city as both space and circulatory system. No topic presents this challenge more clearly than transportation, the most explicitly motive force in urban life" (Prytherch and Cidell this volume: ). This is not a straightforward task, however, because

\footnotetext{
${ }^{1}$ Relational approaches to urbanism are not to be confused with Relational Urbanism, a group of professional architects and urban planners who are involved in developing 3D computer graphics models of urban form (see: www.relationalurbanism.com accessed August 2014).
} 
the relational and the territorial are always co-constituted in urban space (McCann and Ward 2010). The flows and networks connecting cities and the spaces therein still require the production of physical transportation systems, a fact not lost on the likes of David Harvey, who has consistently emphasized that the production of urban space creates tensions between mobility and fixity (Harvey 1982; 1985a). The kind of fixity Harvey has in mind is not one that examines the urban as fixed territorial container; instead it recognizes how the tensions between mobility and spatial fixity are bound up in wider social relationships: how capital and labor power are brought together in the city, how urbanization underpins the accumulation of capital, how various urban-based political coalitions organize to channel the circulation of capital through the built environment, and how devaluation constantly pose a threat to fixed capital invested in the built environment (Harvey 1978). Sheller and Urry (2006: 210) echo Harvey when suggesting that different forms of mobility require placespecific investments in immobile infrastructure, giving rise to different social and political constructions of locality. So when thinking about geographies of mobility, we should not forget the continuing importance of spatial fixity in its various social and physical forms.

Transportation geography has a longstanding interest in the relationship between transportation, mobility, and urban development (Harris and Ullman 1945; Taaffe, Morrill and Gould 1963; Berry 1964; Taaffe and Gauthier 1973; Hanson and Giuliano 2004). There is no need to rehearse this history here. What I will say, however, is that the study of urban transportation geography has in some ways contributed to the kind of containerized view of the city that has become the bane of relational urban scholars. It is manifested, for instance, in the division of labor between those who study intra-urban transport systems, such as light rail and bus transit, and those interested in inter-urban systems, such as the airline industry, freight traffic and high speed rail. Yet most urban transportation networks and their systems 
of governance do not stop at the jurisdictional limits of the city; even if, as the residents of Detroit would probably attest, one's personal experiences of mobility are often profoundly shaped by the presence of urban political boundaries. Similarly, the development of interurban transport systems can have important implications for territorial politics. Thus, for instance, recent proposals in the United Kingdom for new high-speed rail network linking London and the regions have highlighted a growing territorial-political divide between London and those cities located outside the core urban growth region of the South East of England (Tomaney and Marques 2013). Approaching urban transportation from the perspective of mobility not only renders the academic division of labor between inter- and intra-urban transportation geography anachronistic; it also promises to unsettle the territorial/relational divide in urban theory.

What further sets this book apart from previous encounters between transportation and urban geography is its approach to questions of mobility. The emphasis is not on drawing fixed boundaries around the urban; nor is it attempting to treat transportation as an independent spatial variable - a locational cost surface -- shaping urban spatial form. Instead, the chapters animate relational understandings of the city by means of cross-cutting themes, such as the changing role of urban spaces and places within wider transportation networks and flows, the governance of urban mobility and transportation systems, the manner in which different modes of transportation are experienced and imagined, and how cities and transportation networks are co-produced through new patterns of circulation. In doing so, the contributors reveal that transport systems are more than engineered structures which physically constrain and limit urban spatial form; rather they increasingly involve complex social, technical, and political systems and relationships which connect, define, and delimit urban space. I shall refer to this as the urban-transportation-geography nexus. 
In the remainder of this concluding chapter, I wish to build on each of the sections in the book and propose four themes for further work on the urban-transportation-geography nexus, and how work in this volume contributes to them. Firstly, and elaborating on the discussion of intersections, I refer to the literature on ordinary urbanism and suggest that patterns of mobility in the city are not just the result of decisions by urban planners, public authorities and growth coalitions; they also reflect how normative rules and regulations governing flows of traffic and people are interpreted, enacted and performed by ordinary urbanites (whether commuters, truck drivers, pedestrians or cyclists). Secondly, I consider how the conjuncture of the politics of mobility, sustainability and climate change is engendering all sorts of new and unexpected political alignments and coalitions around the urban living place. In section three, I examine how work on the provision and consumption of transportation infrastructures provides an opportunity to explore changes in state territoriality. Investments in urban infrastructure not only create new networks and flows across state territory, they also lend legitimacy to new discourses of territorial competition and city-regional growth. Several of the chapters speak to the evolving relationship between the production of urban mobility, the investment strategies of the competition state, and the governance of city-regions. The fourth section makes a link between reconnecting urban and regional spaces and reimaging urban worlds. It examines how the urban governance challenges of mobility inform how powerful interest groups discursively represent, imagine and market urban regions, cities, and the spaces within and between them. I conclude by reflecting on how the above themes might point us in the direction of several promising routes for exploring questions of mobility, relations, flows, territories, and the production of urban space. 


\section{Ordinary urbanism: the experience of transport and mobility in the city}

As explored in the first section of the book, fixed investments in transportation infrastructure not only connect urban places to the wider global economy, they also change everyday movement patterns and flows across the city and its jurisdictional limits. In so doing, urban mobility profoundly yet at the same time surreptitiously shapes and reshapes what Giddens (1984) has called the "structuration of everyday life" in the city and its constituent locales. Mobility is essential to how cities work in both a literal and figurative sense: how labor is performed (and exploited) in the city, how commuters get to work, and how people make a living, right down to the level of the street (Jonas, McCann and Thomas 2015). If past urban models expressed a bird's-eye-view of the city, the editors offer instead a street-level perspective of Chicago: "Standing at major intersections, like where Michigan Avenue and Wacker Drive join in Chicago's Loop, one is struck less by surrounding skyscrapers than the incessant, negotiated circulation of cars and bike and buses on the streets, pedestrians along sidewalks and up staircases and elevators, elevated trains rumbling above and the subway below, passenger and cargo planes criss-crossing the sky, and boats traveling along the Chicago River whose portage between the Great Lakes and Mississippi watersheds made the city possible..." (Prytherch and Cidell this volume: )

Prytherch and Cidell invite us to engage with such spaces with empirical sensitivity and theoretical rigor so that we can better appreciate how cities function as places where ordinary urban lives are experienced, negotiated, and contested.

Several chapters use mobility to explore what Jennifer Robinson calls the geography of “ordinary cities” (Robinson 2006). David Prytherch (this volume) examines street intersections as locales where particular "rules of the road" like statutory law and traffic control choreograph everyday geographies of mobility. Drawing upon Merriman (2012), he 
interprets mobility as variously comprised of practices, technologies, discourses and bodily movement in space. Focusing on particular urban spaces - such as an intersection in Hamilton, Ohio - reveals how federal, state, and local rules structure the spatiality of social life and mobility in the city. Meanwhile, Gregg Culver (this volume) invites us to reflect on how traffic engineering tools like levels of service (LOS) reinforce normative spatial visions of mobility. LOS is a way of classifying operating conditions for a given stretch of highway into six different levels, ranging from "best" (A) to "worst" (F). Culver attempts to make sense of two interrelated processes: first, how traffic engineering informs normative spatial visions of mobility; and, second, how values and assumptions embedded in such tools become naturalized as state-of the-art science deployed - discursively and materially - in major infrastructure projects, prioritizing fluid automobility over alternative modes.

If traffic codes, rules, regulations, and design standards (like LOS) govern mobility in a formal sense, urban scholars are also interested in how the experience of ordinary urbanism can subvert such received rationalities. Bascom Guffin's chapter (this volume) considers how formal traffic regulations are negotiated and contested in the cities of the global South and what this says about urban theories based on observations in the cities of the global North. In Hyderabad, India, drivers use horns rather than brakes to negotiate through traffic. They tend to see abstract traffic regulations as obstacles, at best, to be avoided or, at worst, completely disregarded. Instead, a bodily politics of mobility takes shape, where traffic is channelled more by concrete than compliance with rules. The fact that the everyday mobility in Hyderabad diverges from the norm does not make it exceptional or resistant to explanation. Instead, urban theory must fully embrace such differences in the ordinary experiences of mobility. 


\section{Transportation, mobility and the environment}

Following the Rio Earth Summit Conference of 1992, many urban authorities responded to the call for sustainable development by signing up to initiatives such as Local Agenda 21. Promoting sustainability has since become a concerted focus of activity in the part of urban growth coalitions (While, Jonas, and Gibbs 2004), leading to a new raft of interventions around the built environment, transportation, and urban living place. Interventions --such as re-densification, smart growth, and transit-oriented development -- attempt to generate socially-equitable and environmentally-sustainable geographies of urban flow, movement, and encounter. Here the state, via urban planning, attempts to influence the geography of land values, thus altering the relationship between transportation, the urban land nexus, and the process of capital accumulation (Scott 1980). At the same time, new demands are being put on urban leaders to invest in physical infrastructures and urban forms which rely less on the burning of fossil fuels. The discursive landscape of urban development is rapidly becoming colonized by references to sustainability, climate adaptation, and the low-carbon economy, each in its turn a sign of a "new environmental politics of urban development" (NEPUD) (Jonas, Gibbs and While 2011).

The spaces where these new politics play out are battlegrounds between conflicting visions and political rationalities underpinning discourses of mobility, sustainability, and economic growth. Focusing on one such space in Vancouver, Canada, Peter V. Hall (this volume) examines the ways particular transportation corridors are planned and accepted (or contested) as routes for truck movement, thereby differentiating and dividing metropolitan communities and places. This results, in part, from the combined effects of the accumulated residue of prior fixed investments, sunk costs, planning laws, and environmental regulations. However, 
such effects are reinforced by political struggles around mobility on the part of property owners, who are sensitive to differences in land values associated with proximity to known truck routes, and neighborhood organizations concerned about noise, pollution, and health. It seems to Hall that truck routes display rather more resilience than might be expected given the increasingly dynamic and complex patterns of flow they must channel.

As Jason Henderson $(2006,2013)$ has pointed out elsewhere, there are all sorts of possibilities for unusual political alignments to occur around the politics of mobility. In San Francisco, for instance, a form of these politics has been built on the legacy of prior inner-city urban protests. In the 1950s, the city's regional transportation plans triggered a "freeway revolt" in lower-income and working-class neighborhoods scheduled for clearance and urban renewal. Henderson (this volume) takes the San Francisco story forward and argues that wider-scale discussions about transport and climate change must be downscaled to the level at which street intersections and bus stops are planned and governed. Localized interventions like prioritizing transit, pedestrians, and bicycles seek to produce measurable impacts, such as reducing greenhouse gas emissions and vehicle miles traveled (VMT), but these techniques are fiercely contested. Likewise, interventions conducted in the name of smart growth, such as transit-oriented development, rezoning, and densification can achieve certain sustainability benefits, yet can also further exacerbate issues of housing affordability, exclusion, and displacement. This prompts Henderson to conclude that the struggle around climate change is "not just a street fight, but also a struggle over the right to the city."

Urban struggles around mobility sharpen awareness of distributional inequalities across the city. It is well known that suburban development privileges white middle-class households and exposes low-income groups and people of color to toxic environmental facilities in their 
communities and neighborhoods (Pulido 2000). In cities like Chicago, USA, people have fled to the suburbs in order to avoid environmental facilities known to be potentially damaging to their health and safety. However, as Julie Cidell's chapter (this volume) shows, new patterns of mobility - including the rerouting of freight traffic from the urban core to suburbs -- have sharpened awareness of environmental inequality. And suburbanites' encounters with freight rail crossing provoke new anxieties and fears of the "uncanny." What sets this conflict apart from more typical struggles located within the suburban living place is mobility - as material practice and signification -- across local jurisdictional boundaries.

\section{Connected cities/competitive states: Transportation, mobility, and the 'geopolitics of capitalism'}

Relational thinking forces us to rethink how mobility shapes and reshapes urban territory. Instead of restricting urban analysis to economic and political structures neatly contained within fixed jurisdictional boundaries - an approach aptly captured by the title of Paul Peterson's (1981) book City Limits - relational urbanism focuses on urban flows, connections, and extra-territorial relations. However, there is no need to throw the baby out with the bathwater; relational approaches are not a substitute for territorial representations of the urban. Instead, mobility allows us to explore the relations of urban space to wider territorial structures of the state.

For example, urban transportation often features in tensions, debates, and political struggles around the state and its territorial structure. On the one hand, mobility shapes how cities are connected across state territory, so decisions about where to build inter-urban transport infrastructure tend to feed into wider political discourses about the state's internal 
functionality as well as its extra-territorial competitiveness (Ward and Jonas 2004). On the other hand, new investments in fixed physical infrastructures can profoundly reconfigure internal state territory in ways that can reinforce existing urban territorial divisions and social exclusions, thereby defining the scope and reach of new urban alliances and coalitions. In each of these respects, investigating the relationship between mobility and the production of urban space can fruitfully provide insights into the reconfiguration of capitalist territoriality, or what Harvey (1985b) has called the "geopolitics of capitalism."

Inspired by the writings of Henri Lefebvre, which emphasize the role of state spatial policy in delivering those physical and social infrastructures essential for sustaining international capital (Lefebvre, 1996), a new generation of urban theorists is interested in exploring the changing role of the state in the production of urban space (Brenner 2000; Brenner and Elden 2009). Under Fordism-Keynesianism, the state's role in enabling accumulation often involved building national transportation networks (freeways, motorways, rail systems, etc.) and organizing state territory into a single, functional, and cost-efficient economic space. The rise of the competition state, however, threatens this seemingly fixed state territoriality, raising questions about the scalar division of powers and resources between the national and the urban, particularly with respect to the delivery and consumption of infrastructure. Such questions throw into new perspective struggles around geographies of collective provision at the metropolitan and local scales (Cox and Jonas 1993), which in turn feed into wider geopolitical discourses and practices associated with the rise of the competition state and its internal territorial configurations (Addie 2013; Jonas 2013).

If, as the editors mention in the introduction, technological changes have allowed for an unprecedented level of locational freedom on the part of corporations and capital, new 
geographies of mobility necessitate new infrastructural connections between urban places and hence also new configurations of state territoriality. Several chapters in this book are able to shed light on how the infrastructural and mobility needs of the competition state engender tensions and conflicts more or less around the scale of the city-region. For example, Theresa Enright (this volume) examines how conflicts over the Grand Paris Express (GPE) rapid transit system are at the same time struggles to define the territorial limits and the extraterritorial reach of the metropolis. The most outspoken voices in the Grand Paris transit debates assume that state powers and resources must be mobilized, both to attract investments to the city-region and enhance its extra-territorial competitiveness. She provocatively describes this new geopolitics of accumulation in terms of a "regime of metromobility" which extends well beyond the territorial limits of the city-region. Likewise, Jean-Paul Addie (this volume) seeks to bridge the relational/territorial divide and demonstrate how transportation mobility shapes the governance of the Toronto city-region. His analysis reveals the contradictory tension between mobility's rendering of metropolitan space as punctuated by flows and rhythms on the one hand, and how managing mobility requires regional governance structures that are simultaneously territorialized and containerized on the other. Both chapters demonstrate how the metropolitan provision of transportation infrastructures underpins the discursive production and active governance of state territoriality through the modern metropolis.

Such changes in state territoriality at the city-regional scale could be indicative of causal connections between accumulation and the growth of regionally-extensive urban forms (Soja 2000, 2011). Most of our received models of urban form, such as those generated by the Chicago School of Social Ecology in the 1920s, are based on city-centric processes and patterns of urban development. Whether the competition between business and consumers for 
central-city locations, or the sorting of retail and service activities across the wider settlement system, scholars have imaged the city developing outwards from the centre, forming neat concentric zones, sectors, nodes and spatial hierarchies. To the extent that Twenty-First Century urbanization is amenable to such forms of rationalization, urban scholars now recognize that processes of urban growth have inverted so that, if anything, growth at the territorial periphery drives change at the centre. Cities are far more decentralized and spread out than ever before, prompting scholars to develop a new vocabulary to describe peripheral settlement forms, such as "edge cities" (Garreau 1991), "post-suburbia” (Phelps and Wu 2011) and "boomburbs" (Lang and LeFurgy 2007), as well as the inner suburbs and older urban districts seemingly left behind by sprawl: Zwischenstadt or the "in-between spaces" of the metropolitan region (Sieverts 2003; Keil 2011).

As entrenched city-suburban political divisions give way to a plurality of geopolitical possibilities, regional urbanization challenges how we think relationally about territorial politics. What was once fought around the politics of urban vs. suburban is now more likely to be manifested as new territorial discourses, such as "global city," "suburban regionalism," "new regionalism" or "regional collaboration" (Jonas 2011; Jonas, Goetz, and Bhattacharjee 2014). Another possibility is further balkanization around self-governing territorial entities, such as special purpose districts, gated communities, and other privatized forms of suburban development, many demanding premium access to regional utilities and transportation infrastructure (Graham and Marvin 2001). Those inner-urban spaces lacking in the corresponding powers and governance capacities, or suffering from the fiscal effects of urban austerity, might be deprived of essential investments in social and physical infrastructures. 
Whereas the chapter by Addie focuses on the divergent experiences of Toronto's in-between spaces, yet other possibilities are revealed in Christian Mettke's chapter (this volume) on mass transit in the Greater Toronto Area (GTA). As the GTA expands and attracts global investment, mass transit is caught up in a dilemma of satisfying new urban growth demands at the same time as it needs to serve deprived areas suffering from limited mobility options. Such spatial deficits in collective provision for mobility bring into the public arena new political voices and understandings about city-regional development. Nowhere is this more important than when we examine mobility and transportation in post-colonial urban contexts and how, in turn, such contexts inform our theories and imaginaries of urban spaces once at the colonial core.

\section{Reworlding, reconnecting, and reimagining the city}

Roy and Ong (2011) consider how concepts of territory and political identity are being challenged by the emergence of new urban forms in post-colonial societies. The urbanization of the global South and the formation of new connections to former colonial centres in the global North have profoundly influenced the imagination and representation of urban space. That post-colonial urban forms challenge many of the territorial rationalities underpinning the development of the metropolis is highlighted in Ananya Roy's analysis of Malaysia's Multimedia Super Corridor (MSC), which connects Kuala Lumpur to the nation's capital in the new suburb of Putrajaya and the nearby high-tech city of Cyberjaya (Roy 2009). Roy argues that the MSC is emblematic of new imaginaries of nation, state, and territory in a hyper-connected world. Similarly, Anru Lee's study (this volume) of the symbolic and cultural meanings of mass transit in the City of Kaohsiung, Taiwan, reminds us of the need to consider how investments in physical infrastructure can become a vehicle of not only physical movement but also of change, breaking away, and becoming. The Kaohsiung Mass 
Rapid Transit System has enabled not only the possibility of flow for the city's population but also, as Lee suggests, "the flow of the city into a brighter and more prosperous future."

An alternative perspective on mobility and urban representation is offered in the chapter by Bianca Freire-Medeiros and Leonardo Name (this volume). They examine the Complexo do Alemão, a recently pacified favela (shanty town) in Rio de Janeiro, Brazil. A multi-million cable car system known as Teleférico do Alemão takes tourists on a 16 minute ride above the favela to the top of a mountain. Deploying the notion of the "traveling favela," they show how international tourists and celebrities journeying on the cable car have turned the favela into a set of visually appealing photographic images and brochures. The huge popularity of the Teleférico inspires the authors to script a new stage in the biography of the traveling favela: its consolidation as a global tourist attraction through the production of new transportation mobilities.

Moving beyond the central city into the wider region, one enters into zones, jurisdictions and areas often lacking in clear territorial markers and political identities. If mobility shapes the relational character of places, the planning and regulation of these in-between spaces nevertheless often requires the imposition of new territorial meanings on the landscape. As Cox and Mair (1988) argue, often it is local actors dependent on growth who strive to fill the void in meaning and signification created by capital mobility. In this manner, the local becomes a space to be colonized by ideologies of community, territory, or place. In his chapter, Markus Hesse (this volume) distinguishes between economic development strategies that promote progressive ideologies and visions of regional growth based around logistics, and other arguably more restrictive attempts that draw on alternative meanings and ideologies, such as sustainability and community empowerment. In the former category are 
the place promotion efforts of regions and states involved in selling and promoting regional hubs or national logistic centres. In the latter are local land use plans and restrictions which seek to defend local use values. Each strategy in its turn entails different and conflicting imaginaries of region and place.

Further evidence of conflict around the meaning of territory is provided in the chapter by Sophie Van Neste (this volume) who considers how new infrastructure projects in the inbetween spaces of the Randstad region of the Netherlands are strategically framed and counter-framed by regional authorities and local residents. At issue is the meaning of a place known as Midden-Delfland in South Holland. In the past, Midden-Delfland had specific qualities and environmental amenities reminiscent of an older Dutch landscape, and which have been promoted by local nature groups, resident associations, and municipalities. However, a new national government, working in partnership with the City and Port of Rotterdam, seeks to develop a highway project across the region, giving a new meaning to Midden-Delfland. It has been reduced, in effect, to a space in-between cities: one characterized in terms of missing highway segments rather than having a coherent sense of place. Van Neste refers to this meaning-giving process as one of "place-framing" and, in so doing, demonstrates that the territorial signifiers used to describe metropolitan areas and the spaces between them are fluid, contested and inherently political.

\section{Final thoughts}

This book has much to say on the matter of relational versus territorial representations of urban space. Unlike previous dialogues between transportation and urban geography, however, it does not start out by drawing strict boundaries between intra- and inter-urban transportation systems, flows and spaces. Rather it uses mobility to think about systems, 
spaces and flows both within, and stretched across, the jurisdictional limits of urban territory. Investigating new modalities of flow and movement across the city and the wider region holds out the promise of changing the way we think relationally about territory - not least urban territory in all of its various physical and social manifestations. As Mimi Sheller suggests in her Preface (this volume: ), we need "to understand spatiality in more relational ways, and to understand the relations enabled by transport in more mobile ways." This book points us in the right direction for pursuing this task.

I have identified four themes which I think could usefully inform future research on transportation, mobility, and the production of urban space. Firstly, there is further scope to examine how rules and regulations governing flows of traffic and people are interpreted and enacted by residents in "ordinary cities" and to use these insights to advance critical urban theory. Secondly, the convergence of the politics of mobility and that of climate change seems throws into sharp perspective new political struggles and social movements around planning and social provision in the city. Thirdly, transportation mobility provides an opportunity to investigate tensions and struggles around the territorial structures of the competition state. Finally, the governance of mobility feeds into new representations and imaginaries of city-regions and the spaces in between. Whilst I am sure that readers will have their own suggestions, I believe that each of these themes opens up all sorts of new avenues for exploring questions of mobility and the social production of space at the urbantransportation-geography nexus.

\section{Acnowledgements}


Thanks to the editors for their helpful comments and to Andy Goetz and Eric Boschmann for reminding me of the importance of transportation for how we explore and experience processes of urban development.

\section{References}

Addie, J-P. (2013) "Metropolitics in motion: The dynamics of transportation and state reterritorialization in the Chicago and Toronto City-regions," Urban Geography, 34(2):188-217.

Amin, A. and Thrift, N. (2002) Cities: Reimagining the Urban. Cambridge: Polity.

Berry, B. (1964) "Cities as systems within systems of cities," Papers in Regional Science, $13: 147-164$.

Brenner, N. (2000) "The urban question as a scale question: Reflections on Henri Lefebvre, urban theory, and the politics of scale," International Journal of Urban and Regional Research, 24:360-377.

Brenner, N. and Elden, S. (Eds.) (2009) State, Space, World: Selected Essays, Henri Lefebvre, Minneapolis: University of Minnesota Press.

Castells, M. (2000) The Network Society, Cambridge, MA: Blackwell ( $2^{\text {nd }}$ edition).

Cox, K. R. and Mair, A.J. (1988) "Locality and Community in the Politics of Local Economic Development," Annals of the Association of American Geographers, 78:307-25.

Cox, K. R. and Jonas, A. E. G. (1993) "Urban Development, Collective Consumption and the Politics of Metropolitan Fragmentation," Political Geography, 12:8-37.

Cresswell T, (2010) “Towards a Politics of Mobility," Environment and Planning D, 28(1):17-31.

Garreau, J. (1991) Edge City: Life on the New Frontier. New York: Doubleday. 
Giddens, A. (1984). The Constitution of Society: Outline of the Theory of Structuration, Cambridge: Polity Press.

Graham, S. and Marvin, S. (2001) Splintering Urbanism: Networked Infrastructures, Technological Mobilities and the Urban Condition. London: Routledge.

Hall, P. and Hesse, M. (Eds.) (2013) Cities, Regions and Flows. Abington, Oxon: Routledge. Hanson, S. and Giuliano, G. (Eds.) (2004) The Geography of Urban Transportation. New York, Guilford ( $3^{\text {rd }}$ edition).

Harvey, D. (1978) “The Urban Process Under Capitalism: A Framework for Analysis,” International Journal of Urban and Regional Research, 2:101-131.

Harvey, D. (1982) The Limits to Capital, Oxford: Blackwell.

Harvey, D. (1985a) The Urbanization of Capital, Baltimore: The Johns Hopkins University Press.

Harvey, D. (1985b) “The Geopolitics of Capitalism,” in Gregory, D. and Urry, J. (Eds.) Social Relations and Spatial Structures, London: MacMillan, 128-163.

Henderson, J. (2006) "Secessionist Automobility: Racism, Anti-urbanism, and the Politics of Automobility in Atlanta, Georgia," International Journal of Urban and Regional Research, 30(2):293-307.

Henderson, J. (2013) Street Fight: The Politics of Mobility in San Francisco. Amherst: University of Massachusetts Press.

Heynen, N., Kaika, M. and Swyngedouw, E. (2006) In the Nature of Cities: Urban Political Ecology and the Politics of Urban Metabolism. Abingdon: Routledge.

Jonas, A.E.G. (2013) “City-regionalism as a Contingent 'Geopolitics of Capitalism,"” Geopolitics 18(2):284-298.

Jonas, A.E.G. (2011) "Post-suburban Regionalism: From Local Politics of Exclusion to Regional Politics of Economic Development," in Phelps, N.A. and Wu, F. (Eds.) 
International Perspectives on Suburbanization: A Post-Suburban World?

Basingstoke: Palgrave Macmillan, 81-100.

Jonas, A.E.G., Gibbs, D.C. and While, A.H. (2004) "State Modernisation and Local Strategic Selectivity after Local Agenda 21: Evidence from Three Northern English Localities," Policy and Politics, 32:151-68.

Jonas, A.E.G., Gibbs, D. and While, A. (2011) "The New Urban Politics as a Politics of Carbon Control," Urban Studies, 48:2537-2544.

Jonas, A.E.G., Goetz, A.R. and Battarcharjee, S. (2014) "City-regionalism and the Politics of Collective Provision: Regional Transportation Infrastructure in Denver, USA,” Urban Studies, 51(11):2444-2465.

Jonas, A.E.G., McCann, E. and Thomas, M. (2015) Urban Geography: A Critical Introduction. Oxford, Wiley-Blackwell.

Kaika, M. (2005) City of Flows: Nature, Modernity and the City. New York, Routledge.

Keil, R. (2011) “The Global City Comes Home: Internalised Globalisation in Frankfurt Rhine-Main,” Urban Studies, 48:2495-518.

Lang, R. E. and J. LeFurgy (2007) Boomburbs: the Rise of America's Accidental Cities. New York: Brookings Institution.

Lefebvre, H. (1996) Writings on Cities, translated and edited by E. Kofman and E. Lebas, Cambridge, MA: Blackwell.

Massey, D. (1991) “A Global Sense of Place,” Marxism Today, 35(6):24-29.

Massey, D. (2007) World City. Cambridge: Polity Press.

McCann, E., and Ward, K. G. (2010) "Relationality/Territoriality: Toward a Conceptualization of Cities in the World," Geoforum, 41(2):175-184.

Merriman, P. (2012) "Human Geography Without Time-Space," Transactions of the Institute of British Geographers, NS 37:13-27. 
Peterson, P. (1981) City Limits. Chicago: University of Chicago Press.

Phelps, N. A. and Wu, F. (Eds.) (2011) International Perspectives on Suburbanization: A Post-Suburban World? Basingstoke: Palgrave Macmillan.

Pulido, L. (2000) "Rethinking Environmental Racism: White Privilege and Urban Development in Southern California," Annals of the Association of American Geographers, 90(1):12-40.

Robinson, J. (2006) Ordinary Cities: Between Modernity and Development. New York: Routledge.

Roy, A. (2009) “The $21^{\text {st }}$ Century Metropolis: New Geographies of Theory,” Regional Studies, 43:819-30.

Roy, A. and Ong, A. (Eds.) (2011) Worlding Cities: Asian Experiments and the Art of Being Global. Oxford: Wiley-Blackwell.

Scott, A. J. (1980) The Urban Land Nexus and the State. London: Pion.

Shaw, J. and Hesse, M. (2010) "Transport, Geography, and the "New" Mobilities," Transactions of the Institute of British Geographers, 35(3):305-312.

Sheller, M. and Urry, J. (2006) “The New Mobilities Paradigm,” Environment and Planning A, 38(2):207-226.

Sieverts, T. (2003) Cities Without Cities: An Interpretation of the Zwischenstadt. London: Spon Press.

Soja, E. (2000) Postmetropolis: Critical Studies of Cities and Regions. Oxford: Blackwell.

Soja, E. (2011) "Regional Urbanization and the End of the Metropolis Era," in Bridge, G. and Watson, S. (Eds.) The New Blackwell Companion to the City. Oxford: WileyBlackwell, pp. 679-89.

Taaffe, E. and Gauthier, H. (1973) Geography of Transportation. New York: Prentice-Hall. Taaffe, E., Morrill, R., and Gould, P. (1963) “Transport Expansion in Underdeveloped 
Countries: A Comparative Analysis," Geographical Review, 53(4):503-529.

Tomaney, J. and Marques, P. (2013) "Evidence, Policy, and the Politics of Regional

Development: The Case of High-Speed Rail in the United Kingdom,” Environment and Planning C, 31(3):414-427.

While, A., Jonas, A.E.G., and Gibbs, D.C. (2004) “The Environment and the Entrepreneurial City: Searching for a "Sustainability Fix" in Leeds and Manchester," International Journal of Urban and Regional Research, 28:549-569.

Ward, K. and Jonas, A.E.G. (2004) "Competitive City-Regionalism as a Politics of Space: A Critical Reinterpretation of the New Regionalism," Environment and Planning A, $36: 2112-39$.

\section{Biographical information}

Andy Jonas is Professor of Human Geography at Hull University in the United Kingdom. His $\mathrm{PhD}$ is from The Ohio State University, USA. He has published widely on urban development politics and the provision of infrastructure in US and European cities and regions. His latest book, co-authored with Eugene McCann and Mary Thomas, is Urban Geography; A Critical Introduction (Wiley-Blackwell). His co-edited books include The Urban Growth Machine: Critical Perspectives Two Decades Later (SUNY Press, 1999), Interrogating Alterity (Ashgate, 2010), and Territory, State and Urban Politics (Ashgate, 2012). 